DIGITAL COMMONS
@ UNIVERSITY OF SOUTH FLORIDA

Volume 9

Issue 1 Special Issue: Eighteenth-Century Camp

\section{ABO: Interactive Journal for Women in the Arts, 1640-1830}

Article 6

2019

\title{
Review of Abigail Williams's The Social Life of Books: Reading Together in the Eighteenth-Century Home
}

Andrea L. Coldwell

Coker College, acoldwell@coker.edu

Follow this and additional works at: https://digitalcommons.usf.edu/abo

Part of the Educational Methods Commons, Literature in English, British Isles Commons, and the Reading and Language Commons

\section{Recommended Citation}

Coldwell, Andrea L. (2019) "Review of Abigail Williams's The Social Life of Books: Reading Together in the Eighteenth-Century Home," ABO: Interactive Journal for Women in the Arts, 1640-1830: Vol.9: Iss.1, Article 6.

https://doi.org/10.5038/2157-7129.9.1.1212

Available at: https://digitalcommons.usf.edu/abo/vol9/iss1/6

This Reviews is brought to you for free and open access by Digital Commons @ University of South Florida. It has been accepted for inclusion in ABO: Interactive Journal for Women in the Arts, 1640-1830 by an authorized administrator of Digital Commons @ University of South Florida. For more information, please contact digitalcommons@usf.edu. 
Review of Abigail Williams's The Social Life of Books: Reading Together in the Eighteenth-Century Home

\section{Creative Commons License}

\section{(c) (1) \&}

This work is licensed under a Creative Commons Attribution-Noncommercial 4.0 License 
Abigail Williams. The Social Life of Books: Reading Together in the Eighteenth-Century Home. Yale University Press, 2018. viii + 351pp. ISBN: 9780300240252.

Reviewed by Andrea L. Coldwell

Coker College

With The Social Life of Books, Abigail Williams presents "a series of vignettes of reading lives and practices" that challenge and complicate notions about reading during the eighteenth century (275). Using a variety of primary sources, she addresses many assumptions and questions about reading as well as the possession and circulation of books during the eighteenth century. Such assumptions result when studies of reading focus on the creators of texts or on reading as a solitary exercise. While Williams engages with the existing studies on solitary reading, she also uses manuscript materials, elocution guides, domestic inventories, and other less familiar sources to paint a picture of communal reading. As Williams would have it, "A history of sociable reading puts books back into lives and homes, enabling us to see literature in the round" (3). This technique raises questions about the meaning of reading itself in the eighteenth century and about the cultural fears that emerged with an expanded reading public. At the same time, it opens new possibilities for understanding what and how people read during this period as well as what significance they attached to different variations on the act of reading.

Williams begins her study with "How to Read," examining the study of elocution as an art. She shows how increasing attention to clergymen's performance of prewritten or printed sermons created a listening public attuned to a specific style of performative reading. Using elocution guides and personal letters, Williams demonstrates the ways these performances reflected gender and class expectations, insisting on a polished naturalness, an appearance of ease alongside polite accomplishment. The chapter ends by pointing out that such guides shaped what people read as much as how they read. This attention to professional reading resets readers' expectations about what reading is and how it operated in eighteenth-century culture. Chapter 2, "Reading and Sociability," traces occasions for reading, offering examples of useful reading as an accompaniment for useful activity and tracking both actions as opportunities to display virtue. Her reading of inventories also shows that most books were stored in social parts of the house, which suggests that most reading also took place there, though Williams also notes that social reading was common on outings and during travel. These two chapters set the pattern for the rest of the book in using brief references and end notes to gesture to existing scholarship on reading. Williams takes these studies as a point of departure, locating her own questions about reading in the assumptions and patterns agreed on by earlier scholarship and challenging scholarly commonplaces about reading practices.

With "Using Books," Williams shifts her focus to the ways physical books affected reading and were influenced by reading practices, mentioning concerns about light, eyestrain, and typeface. Likewise, she cites Leah Price and Peter Stallybrass on reading habits, arguing that contemporary habits of partial reading may have affected the forms of novels and poetry, a claim to which she returns in later chapters where scholars of genre may find matter for debate. Here, she focuses on how social reading could enable conversation and allow for the cultural supervision of less powerful or educated groups. Williams points out that "useful does not always mean practically informative but rather, socially enabling" (88) and that readers' attempts 
to demonstrate and meet expectations of politeness, decorousness, and decency may have led to habits of excerpting and skipping. Her careful discussion of usefulness is notable in our own moment when different "uses" for educational and cultural experiences are again under debate. Chapter 4, "Access to Reading," considers where and how readers accessed reading materials, including clubs, libraries, and personal purchases. Here, Williams emphasizes the relationship of class to access and points to the importance of excerpts and poetry in the emerging periodical literature, allowing for wider readership than expensive single or multivolume works. These details contextualize the ways that adjacent readers discussed and shared reading material, even if they read those materials in solitary circumstances.

The next chapters, "Verse at Home," "Drama and Recital," and "Fictional Worlds," look at the specific effects of sociable reading practices on individual genres. In her chapter on verse, Williams looks at the process of collecting poetry, both in annuals and anthologies and informally in commonplace books. She claims such collections hint at patterns of "borrowing, reusing, and reworking" by poets and collectors (141). She also notes a belief in the curative power of laughter which exists alongside the tendency for those at all levels, including in "polite" society, to tell rude and cruel jokes. Likewise, in "Drama and Recital," Williams demonstrates how, through dramatic recitation or performance, "the morality of culture was both policed and willfully transgressed" (203). She describes the processes of moral reasoning that led to bowdlerization and other excerpting while also describing the ways in which home performances offered occasion for breaking from the usual rules of conduct. These connections between performance and politeness reflect a domestic aspect of the bawdy and carnivalesque features which scholars have long recognized in the popular culture of the period.

In "Fictional Worlds," Williams is more directly engaged with previous scholarship than elsewhere, citing Ian Watt on the rise of the novel and Jan Fergus on gendered reading and buying patterns. However, her attention to secondary literature is perfunctory. As elsewhere, she uses these studies primarily to outline the borders of her project, using primary sources to chart a new course. She offers evidence that novels, like other genres, were frequently read out of order or in pieces, and that, when performed, they read like plays, claims that raise interesting questions for contemporary scholarship on novels' cultural influence. She also argues, based on reports by readers, that savvy readers were unlikely to confuse novels with life or to overidentify with characters - two fears frequently expressed by cultural critics at the time. This idea will surely raise new discussions due to its challenges to ideas about readerly types and about individual reading practices in both historical and contemporary studies of reading. Finally, she points to short fictions and jest books as aides to "good conversation," noting again the coarse humor enjoyed at all levels (238).

In her last chapter, "Piety and Knowledge," Williams turns to useful and educational books, reflecting, via Richard Altick, on the likelihood of poor children reading to parents and what materials might have formed the bulk of such public reading. She further recognizes the popularity of religious, historical, and polite science works for social reading and conversation, as well as their particular challenges. For example, she shows how using dialogue to present popular science evidences "an ongoing concern about show and performance" (273-4). Williams's use of archival materials helps to restore a complex understanding of classed reading just as her discussions of vulgarity challenged notions of upper-class politeness, both at odds 
with the expectations raised by conduct book authors. Her claims in this section echo the conclusions of much recent work which traces complex responses to didactic materials.

In her afterward, Williams focuses on ways that reading's embeddedness in everyday life complicates the study of eighteenth-century reading habits. She implies that these contexts have often been simplified precisely because they don't align well with scholars' own habits when examining texts. Williams maintains that access is more complicated than noticing the high price of new books and that distinctions between print and manuscript, or between oral and written forms, blur in the contexts of social reading. Likewise, consumer artifacts that reference literary texts may have been purchased by many people for many reasons, some of them non-literary. Scholars, she insists, can only gesture towards the possibilities raised by such objects and problems; they cannot understand the full motivations of buyers and owners, much less the complete cultural picture formed by the objects. In doing so, she highlights the challenges facing students of material culture, even as archival research unearths additional eighteenth-century voices and perspectives. As significantly, she marks how, struggling to cope with changing modes of reading, eighteenth-century readers and thinkers encountered many anxieties that have reemerged in our own cultures in the face of digital technologies. Williams implicitly challenges scholars to see the convergences between eighteenth-century scholarship and contemporary debates on genre and reading.

Williams's book is engaging and enlightening. Her research is thorough and well-presented, and her conclusions are compelling. For some, the sidelining or minimizing of previous scholarship, frequently treated quickly or covered in voluminous footnotes listing a dozen studies at a time, may be a concern. However, as her "Afterward" claims, the strength of such "vignettes" is that through their partial reconstructions they blur the easy certainties of critical commonplaces, many of which are based on solitary reading. By exploring the varieties and contradictions of social reading, Williams points scholars toward new questions and challenges us to complicate and redefine our understandings of essential aspects of reading, readership, and book history. 